\title{
Where Linnaeus meets Wallace: New botanical discoveries highlight the biological shortfalls in the easternmost campos rupestres of Minas Gerais, Brazil
}

\author{
Paulo Gonella, '(D) Carolina M. Siniscalchi ${ }^{2}$ (1) \& Benoit Loeuille ${ }^{3}$ (D) \\ ' Universidade Federal de São João del-Rei, Campus Sete Lagoas, Rodovia MG 424, km 47, Sete Lagoas, Minas Gerais, 3570I-970, Brazil; pmgonella@gmail.com \\ 2 Department of Biological Sciences, Mississippi State University, 295 Lee Blvd, Mississippi State, MS 39762, United States; carol.siniscalchi@gmail.com \\ ${ }^{3}$ Departamento de Botânica, Centro de Biociências, Universidade Federal de Pernambuco, Avenida Professor Moraes Rego, I235, Recife, Pernambuco, \\ 50670-90 I, Brazil; benoit.loeuille@gmail.com
}

DOI: http://dx.doi.org/ | 0.53875/capitulum.0 I . I.05

Keywords: South America, Cerrado, taxonomy, Neotropical mountains.

The concept of biological shortfalls was created to express our deficient knowledge on several aspects of biodiversity. The Linnean shortfall (after Carl Linnaeus, the founder of modern taxonomy) refers to the disparity between named and unnamed species, while the Wallacean shortfall (after Alfred Russel Wallace, founder of biogeography), refers to our fragmentary knowledge on species distribution (Lomolino 2004). Overcoming these shortfalls depends on improving our understanding of species boundaries and increasing collections efforts to cover sampling gaps.

Brazil is home to the greatest plant diversity in the world (BFG 20I8), but such rich biodiversity is far from being completely known, as indicated by the number of new plant species described each year in the country. Furthermore, the distribution of this biodiversity is uneven across the vast Brazilian territory. For instance, the campos rupestres, an herbaceous-shrubby vegetation over quartzite or iron ore mountains, cover less than I\% of the Brazilian territory, however, they are home to nearly I5\% of the Brazilian plant species, also presenting a high endemism rate (Silveira et al. 20 I6). Historically, most of the research on campos rupestres has focused on its core area, the Espinhaço Range (ER), a mountain range spanning over $1,000 \mathrm{~km}$ in the states of Minas Gerais and Bahia, but less focus has been given to disjunct areas. Recent botanical and zoological discoveries have demonstrated the occurrence of this vegetation in the historically neglected mountains of the Rio Doce valley, in eastern Minas Gerais.

These mountains form the João Pinto Formation (Figure I), a set of quartzitic sierras interspersed with granitic inselbergs in the Atlantic Forest Domain. These quartzitic mountains are the Serra do Padre Ângelo (Figure 2) (including Serra do Pinhão), Pico da Aliança, Serra da Onça (Figure 3) and Serra do Boiadeiro (both contained in the Sete Salões State Park) and other smaller fragments around the municipalities of Conselheiro Pena, Alvarenga, and surrounding towns (Oliveira 2000). The first botanical discoveries from these mountains came from "charismatic" families with horticultural interest, such as Orchidaceae and Bromeliaceae, but the area only gained scientific attention after the discovery of the giant carnivorous plant Drosera magnifica Rivadavia \& Gonella (Droseraceae; Gonella et al. 20I5). The botanical expeditions that followed this finding uncovered several new species and records, such as the discovery of new populations of the endangered Vellozia gigantea N.L.Menezes \& MelloSilva (Velloziaceae; Mello-Silva 2018) and novelties in Begoniaceae, Eriocaulaceae, Lamiaceae and, most notably, Asteraceae. 


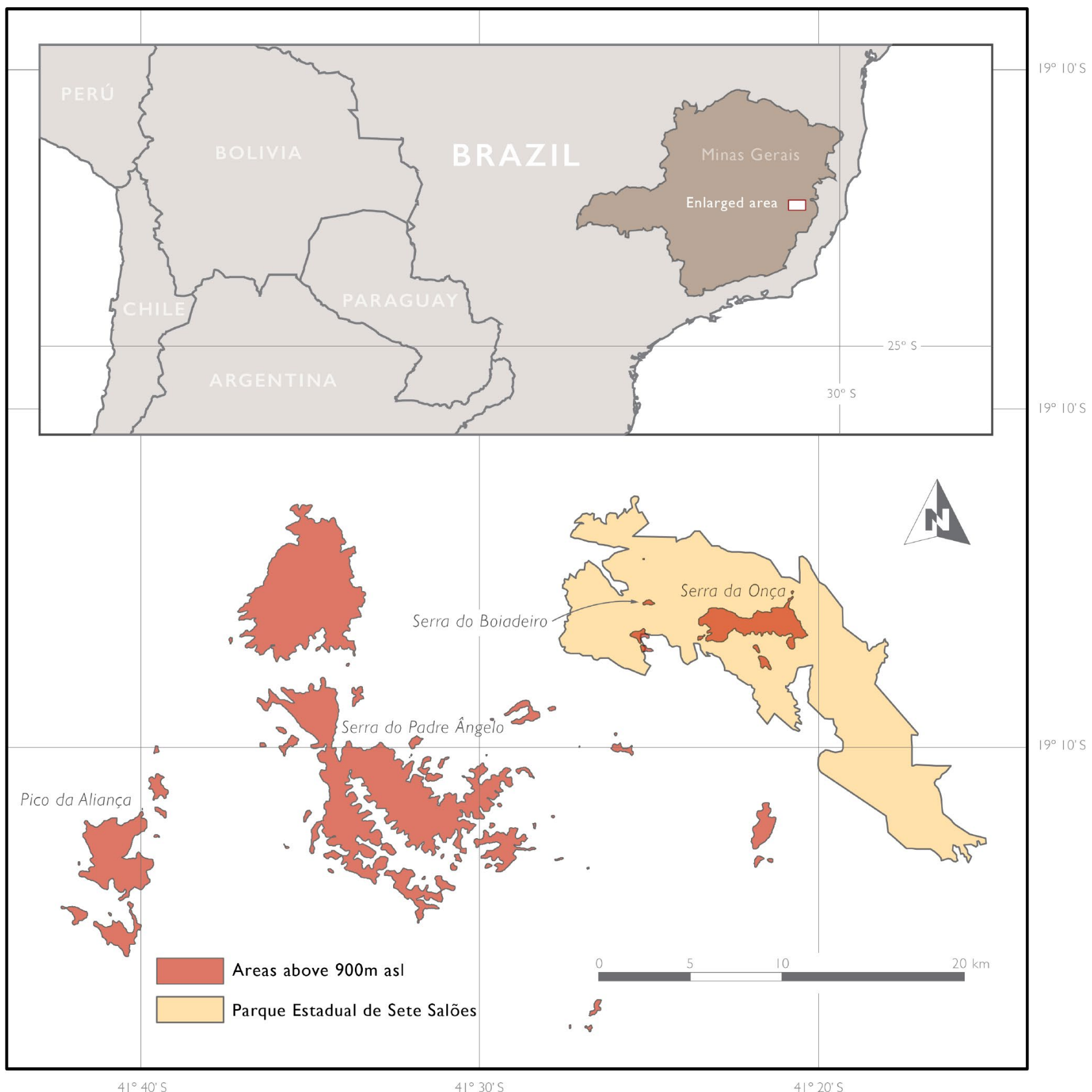

Figure I. Map showing the location of the mountain areas of João Pinto Formation and the single protected area of the region (Parque Estadual de Sete Salões), in eastern Minas Gerais, southeastern Brazil.The campos rupestres are found within areas above $900 \mathrm{~m}$ a.s.l.

Asteraceae is one of the most numerous families in the campos rupestres, with some groups, such as tribe Vernonieae, being especially diverse in this vegetation. The first taxonomic novelties from these mountains, Chresta filicifolia Siniscalchi \& Loeuille and Eremanthus ovatifolius Loeuille \& Pirani, belong to this tribe and were described in 2016 from Sete
Salões State Park and Pico da Aliança, respectively (Loeuille \& Pirani 2016, Siniscalchi et al. 2016). Other novelties came from Pico da Aliança: Lychnophora haplopappa Loeuille, Semir \& Pirani (Figure 4A) was described in 2019 and Lessingianthus petraeus Antar \& Loeuille was described in 2021 (Loeuille et al. 2019, Antar et al. 202 Ia). Serra do 


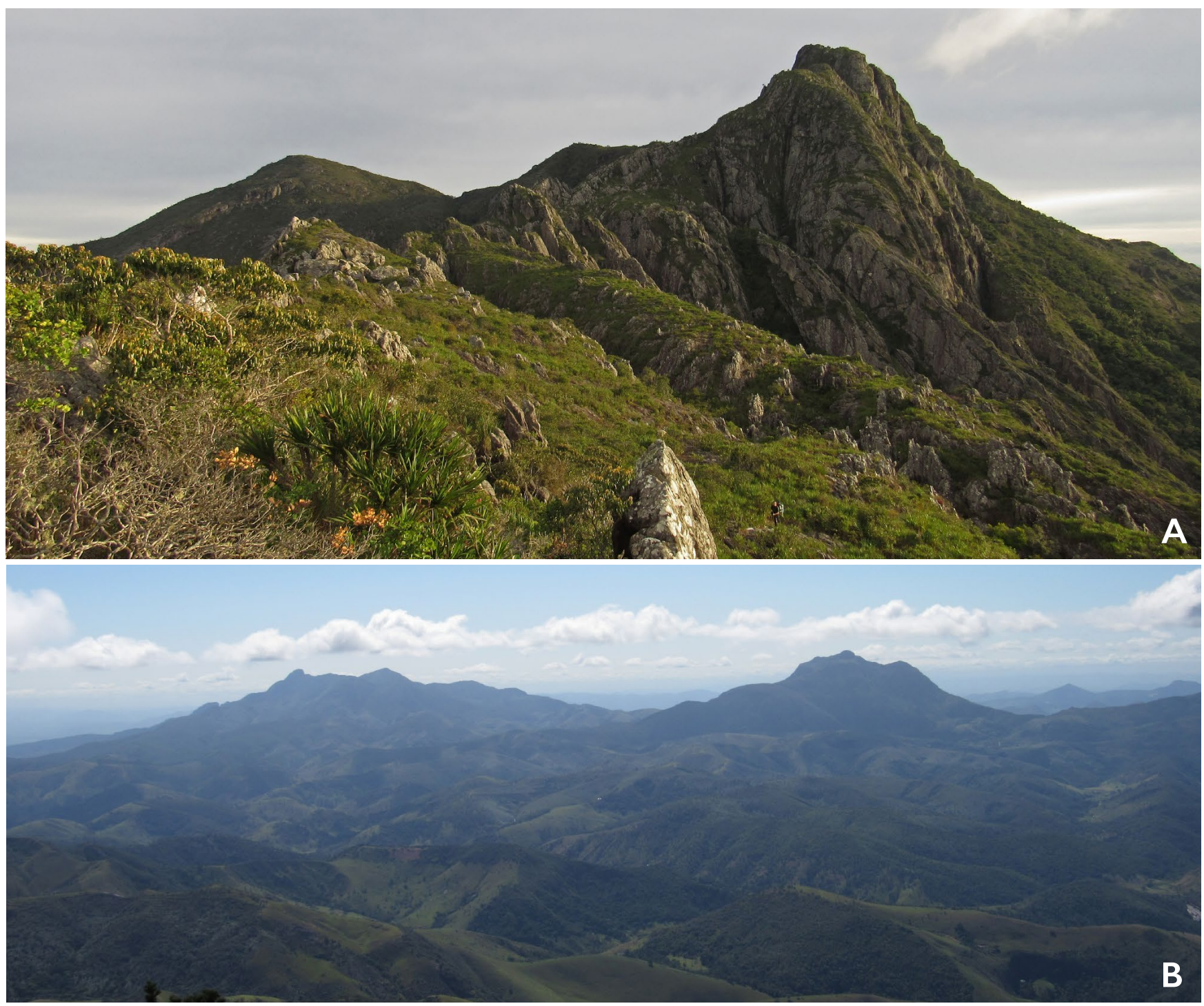

Figure 2. A. The campos rupestres of Pico do Sossego ( 605 m a.s.l.), the highest peak of the João Pinto Formation and part of Serra do Padre Ângelo. B. The mountain complex of Serra do Padre Ângelo, the massif to the left is the Serra do Pinhão, where Pico do Sossego is located, and the massif to the right is the Pico do Padre Ângelo, whose summit reaches 1547 m a.s.l.

Padre Ângelo revealed another new species: Lepidaploa campirupestris Antar \& Loeuille (Antar et al. 202 Ia; Figure 4B). Finally, two Mikania Willd. species should receive a name in the near future.

These findings revealed interesting biogeographical patterns, suggesting an interchange of this biota with the core campos rupestres area, ER, located 200 $\mathrm{km}$ to the West. Notably, most of the diversity of Chresta Vell. ex DC. and Lychnophora Mart. is found in the ER, a pattern also seen in other families like Droseraceae (Gonella et al. 20I5), Eriocaulaceae (Andrino \& Gonella 202I) and Lamiaceae (Antar et al. 202 Ib).
Other new findings in these areas expanded the known distribution of species previously recorded only in granitic inselbergs, such as Cololobus rupestris (Gardner)H.Rob., Lepidaploa opposita A. Teles, Sobral \& J.N.Nakaj, and Lessingianthus squamosus M.Monge \& Semir, representing new records for this quartzitic habitat (Antar et al. 202 la). The close proximity of these two rocky habitats in the region may reveal yet other examples of this ecological disjunction.

While the exploration of the region intensified during the last year thanks to the support of a grant from The Mohamed bin Zayed Species Conservation Fund, we have only scratched the surface of the biodiversity of 


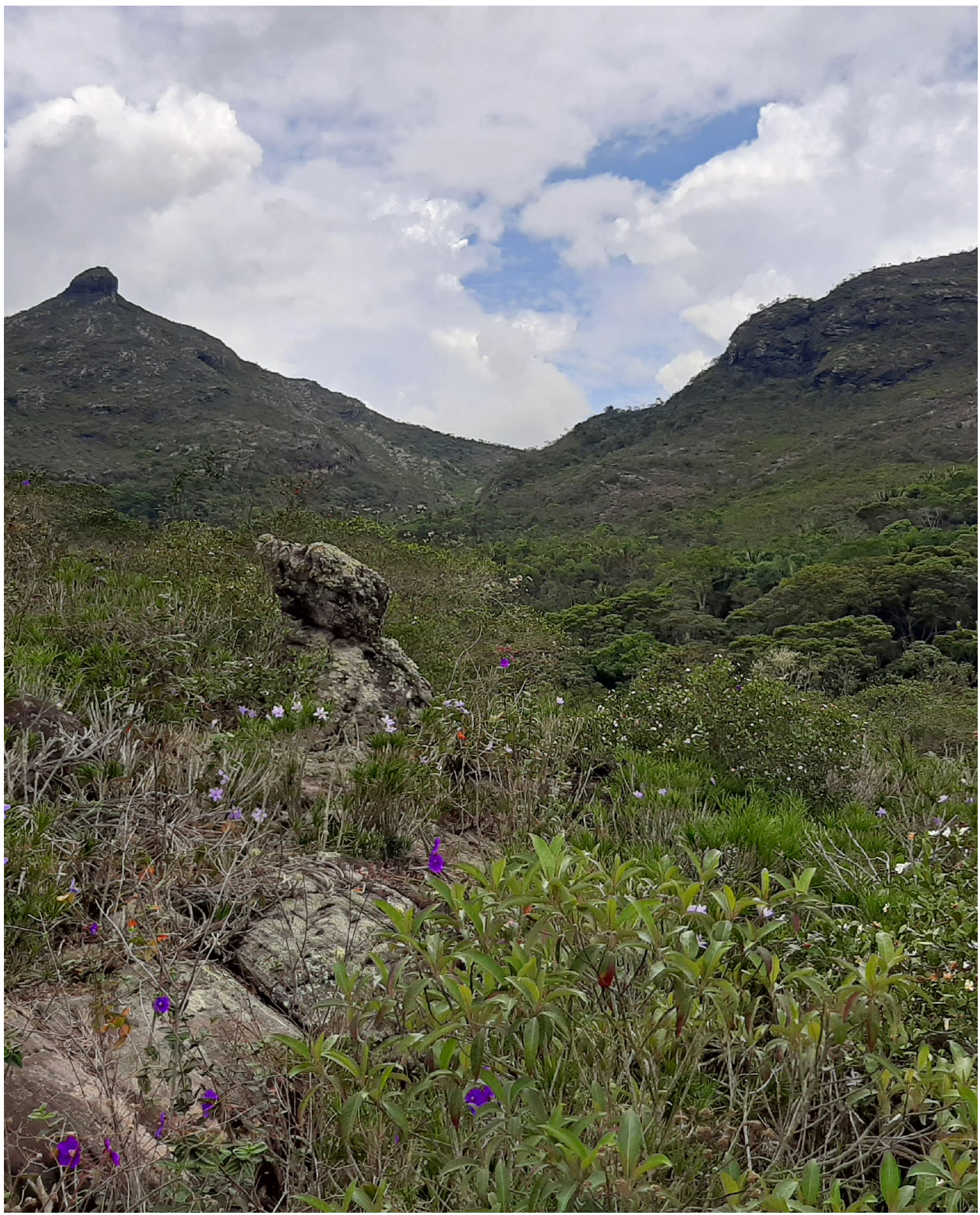

Figure 3. The campos rupestres of Serra da Onça, protected within the Parque Estadual de Sete Salões. The peak to the left in the background is the Pico do Garrafão ( I 49 m a.s.l.). 

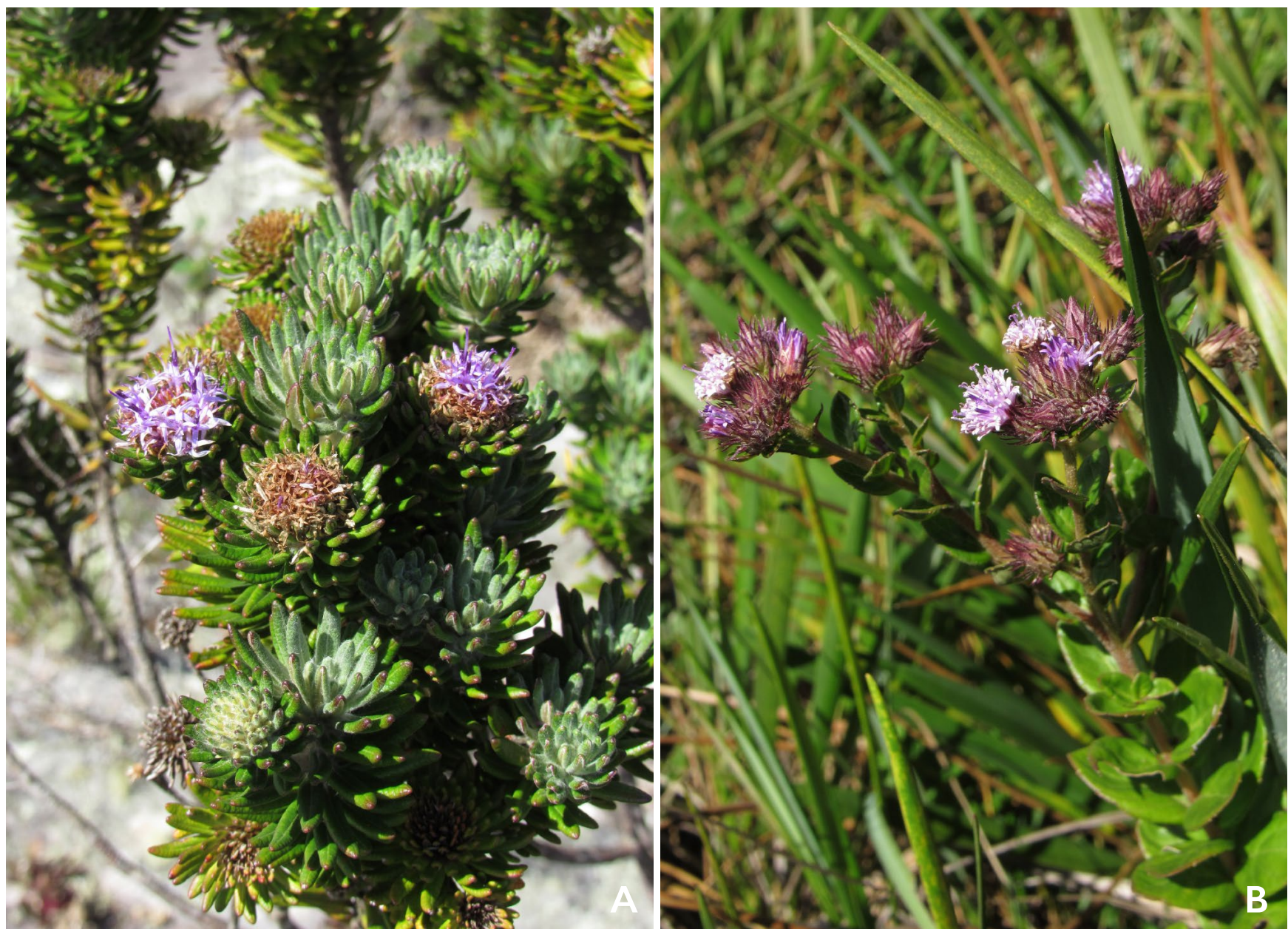

Figure 4. A. Lychnophora haploppapa Loeuille, Semir \& Pirani, species described in 2019 and endemic to Pico da Aliança. B. Lepidaploa campirupestris Antar \& Loeuille, described in 2021 and endemic to Serra do Padre Ângelo, its epithet refers to its singular habitat, the campos rupestres.

these underexplored mountains. Areas such as Sete Salões State Park remain largely undersampled (only 239 biological records from the area are available in the SpeciesLink database, 160 for plants), and may hide several other novelties. Other areas, like Serra do Padre Ângelo, were severely hit by a wildfire in late 2020 and suffer from the lack of protection. These historically neglected areas should be recognized as priority for biological surveys, to overcome the biological shortfalls, and to ground conservation plans to protect its singular, endemic flora.

\section{ACKNOWLEDGMENTS}

We thank The Mohamed bin Zayed Species Conservation Fund (grant 192522325) for support on our study of Campos Rupestres.

\section{LITERATURE CITED}

Andrino C.O. \& Gonella P.M. 2021. An escape from the Espinhaço Range: a new species of Paepalanthus subg. Xeractis (Eriocaulaceae) from the campos rupestres of Serra do Padre Angelo, Minas Gerais, Brazil. Pl. Ecol. Evol. I54: 137-149. DOI : 10.509|/plecevo.202 I.1770

Antar, G.M., Siniscalchi, C.M., Gonella, P.M., Monge, M. \& Loeuille, B. 202 la. Novelties in Lepidaploinae (Asteraceae, Vernonieae) from the easternmost campos rupestres of Minas Gerais, Brazil: two new species and a range expansion. PI. Ecol. Evol. | 54: | 2|-|36. DOl: | 0.509|/plecevo.202 I. 1792

Antar, G.M., Harley, R.M., Pastore, J.F.B., Gonella, P.M. \& Sano, P.T. 202 lb. Hyptidendron pulcherrimum Antar \& Harley, sp. nov. (Hyptidinae, Lamiaceae) a new narrowly endemic species from Minas Gerais, Brazil. Adansonia, sér. 3 43: I-8. DOl: |0.5252/adansonia202 I v43a | 
Brazil Flora Group [BFG]. 2018. Brazilian Flora 2020: Innovation and collaboration to meet Target I of the Global Strategy for Plant Conservation (GSPC). Rodriguésia 69: I 513 | 527. DOI: | 0.1590/2 |75-786020|869402.

Gonella P.M., Rivadavia, F. \& Fleischmann A. 20 I 5. Drosera magnifica (Droseraceae): the largest New World sundew, discovered on Facebook. Phytotaxa 220: 257-267. DOl: | 0.1 | 646/phytotaxa.220.3.4

Loeuille, B. \& Pirani, J.R. 2016. Two new syncephalous species of Eremanthus (Asteraceae: Vernonieae) from southeastern Brazil. Phytotaxa 243: |28-|36. DOI: I0.I |646/ phytotaxa.243.2.2

Loeuille, B., Semir, J. \& Pirani, J.R. 2019. A synopsis of Lychnophorinae (Asteraceae: Vernonieae). Phytotaxa 398: I-139. DOl: I0. I | 646/phytotaxa.398. I.I

Lomolino, M.V. 2004. Conservation biogeography: introduction. Pp. 293-296 in: Lomolino M.V. \& Heaney L.R. (eds) Frontiers of biogeography: new directions in the geography of nature. Sunderland: Sinauer Associates.

Mello-Silva, R. 20 I8. Land of the Giants: remarkable botanical findings highlight a new area for conservation in Brazil. Rodriguésia 69: 933-937. DOI: I 0.1 590/2 I75-7860201869245
Oliveira, M.J.R. 2000. Programa Levantamentos Geológicos Básicos do Brasil. Projeto Leste: Folhas Conselheiro Pena/São Gabriel da Palha - SE.24-Y-C-II/SE.24-Y-C-III (parte), escala I:I 00.000. Belo Horizonte, SEME/COMIG/CPRM.

Silveira F.A.O., Negreiros D., Barbosa N.P.U., Buisson E., Carmo F.F., Carstensen D.W., Conceição A.A., Cornelissen T.G., Echternacht L., Fernandes G.W., Garcia Q.S., Guerra T.J., Jacobi C.M., Lemos-Filho J.P., Le Stradic S., Morellato L.P.C., Neves F.S., Oliveira R.S., Schaefer C.E., Viana P.L. \& Lambers H. 2016. Ecology and evolution of plant diversity in the endangered campo rupestre: a neglected conservation priority. PI. \& Soil. 403: |29-| 52. DOI: |0. I007/s | | |04-0| 5-2637-8

Siniscalchi, C.M., Loeuille, B. \& Pirani, J.R. 2016. A new species of Chresta (Vernonieae, Asteraceae) endemic to the Mata Atlântica Domain, Brazil. Phytotaxa 244: 80-88. DOI: 10.1 1646/phytotaxa.244.1.6 